\title{
Vegetation Database of Observatory Woods, Wisconsin - mapped vegetation
}

\author{
Erika Mudrak, Don Waller \& Brad Herrick
}

\begin{abstract}
Shortly after Observatory Woods (an oak-hickory forest) was purchased by the University of Wisconsin in 1956, Robert Burgess conducted a detailed vegetation inventory via a grid system of $30.5 \times 30.5 \mathrm{~m}$ contiguous stands within 4 hectares. In his Master's Thesis (1959) he provides maps of species distributions of 16 tree species and 138 herbaceous species. In the summer of 2007 I resampled the understory and tree layers of Observatory Woods to investigate changes in local species distributions, and to determine which species are microhabitat specialists and which are microhabitat generalists. Following Burgess 1959, I established a grid of thirty-eight stands, each slightly less than $1 / 4$ acre, in total encompassing about 8 acres. The corners of some of these stands are marked with a permanent stake. Within each stand, I placed fifteen $1 \mathrm{~m}^{2}$ quadrats, totalling 544 throughout the entire forest (property lines cut off some edges). I collected vegetation data on the ground, shrub, and canopy layers, as well as environmental data throughout the forest. This report describes the available content in the Vegetation Database of Observatory Woods, Wisconsin (GIVD ID NA-US-009).
\end{abstract}

Keywords: historical comparison; oak hickory forest; USA.

GIVD Database ID: NA-US-009

Last update: $2012-07-10$

\section{Vegetation Database of Observatory Woods, Wisconsin}

Scope: Shortly after Observatory Woods was purchased by the University of Wisconsin in 1956, Robert Burgess conducted a detailed vegetation inventory via a grid system of $30.5 \times 30.5 \mathrm{~m}$ contiguous stands within 4 hectares. In his MS Thesis he provides maps of species distributions of 16 tree species and 138 herbaceous species. In 2007, 38 of the original stands were resampled with $5441 \mathrm{~m}^{2}$ quadrats for understory species and edaphic and light variables, and $9506 \times 6 \mathrm{~m}$ plots for trees.

Status: completed and continuing

Period: 2007-2007

Database manager(s): Erika Mudrak (emudrak@urgrad.rochester.edu); Brad Herrick (bmherrick@wisc.edu)

Owner: Erika Mudrak with the University of Wisconsin Arboretum

Web address: http://uwarboretum.org/

Availability: according to a specific agreement

Online upload: no

Online search: no

Database format(s): MS Access, Excel

Export format(s): [NA]

Publication: [NA]

Plot type(s): nested plots

Non-overlapping plots: 38

Plot-size range: $1-6 \mathrm{~m}^{2}$

Total plot observations: 1,494

Estimate of existing plots: 1,494

Completeness: $3 \%$

Countries: US: $100.0 \%$

Number of sources: 1

Valid taxa: 154

Forest: $100 \%$ - Non-forest: aquatic: 0\%; semi-aquatic: 0\%; arctic-alpine: 0\%; natural: 0\%; semi-natural: 0\%; anthropogenic: $0 \%$

Guilds: all vascular plants: $100 \%$

Environmental data: microrelief: 100\%; soil depth: 100\%; surface cover other than plants (open soil, litter, bare rock etc.): $100 \%$

Performance measure(s): cover: $100 \%$; number of individuals: $50 \%$; measurements like diameter or height of trees: $100 \%$

Geographic localisation: GPS coordinates (precision $25 \mathrm{~m}$ or less): 100\%

Sampling periods: $2000-2009: 100.0 \%$

Information as of 2012-07-12; further details and future updates available from http://www.givd.info/ID/NA-US-009

Erika Mudrak* (emudrak@urgrad.rochester.edu), Don Waller (dmwaller@wisc.edu)

Botany, University of Wisconsin - Madison, 430 Lincoln Drive, 53706 Madison, Wisconsin, UNITED STATES

Brad Herrick (bmherrick@wisc.edu)

Arboretum, Ecologist and Research Program Manager, University of Wisconsin - Madison, 1207 Seminole Highway, 53711 Madison, Wisconsin, UNITED STATES

*Corresponding author 